TEME, г. XLIII, бр. 3, јул - септембар 2019, стр. 861-883

Прегледни рад

https://doi.org/10.22190/TEME180213052J

Примљено: 13. 2. 2018.

UDK 343.59-057.874(497.11)

Ревидирана верзија: 19. 2. 2019.

Одобрено за штампу: 20. 10. 2019.

\title{
ЗАШТИТА ДЕЦЕ ОД НАСИЉА У СРБИЈИ: АКТУЕЛНА ПРАВНА ПИТАЫА И ПРОБЛЕМИ
}

\author{
Слађана Јовановић", Јелена Арсић \\ Универзитет Унион, Правни факултет, Београд, Србија \\ sladjana.jovanovic@pravnifakultet.rs
}

\begin{abstract}
Апстракт
Систем правне заштите деце од насиља у Србији у последњих неколико деценија карактерише постепено унапређење и хармонизација механизама заштите са међународноправним тенденцијама. Стратешки и други документи подржавају системски приступ и у садејству са релевантним прописима представљају потенцијал за ефикасније решавање проблема насиља над децом. Међутим, одговарајућа примена нормативних решења, као и стратешких докумената и планова, у овој области још увек није у потпуности остварена, укључујући и непрестано праћење реализације утврђених циљева и активности, што представља највећи недостатак постојећег система заштите. У раду су анализиране карактеристике развоја породичноправне и кривичноправне заштите деце од насиља, те могућности и правци њиховог усавршавања - како на нормативном плану тако и у погледу практичне примене постојећих решења.
\end{abstract}

Кључне речи: деца, насиље, породичноправна заштита, кривичноправна заштита.

\section{PROTECTION OF CHILDREN FROM VIOLENCE IN SERBIA: CURRENT LEGAL ISSUES AND PROBLEMS}

\begin{abstract}
Throughout the last several decades, the system of legal protection of children from violence in Serbia has been gradually improving, and its protection mechanisms have been harmonizing with international legal tendencies. Strategic and other documents support the systemic approach and, in conjunction with relevant regulations, represent the potential for more efficient solution of the problem of violence against children. However, adequate implementation of the existing legal norms, as well as strategic documents and plans in this field, has not yet been fully accomplished, including the continuous monitoring of the achievement of established goals and activities, which represents the major deficiency of current protection system. This paper analyzes characteristics of the development of family law and criminal law protection of children from violence, as well as the possibilities and pathways for its improvement, both in terms of normative and practical implementation of the existing solutions.
\end{abstract}

Key words: children, violence, family law protection, criminal law protection. 
Бројна истраживања сведоче о томе да су деца изложена ризику од насиља у породици, али и ван породице, од стране њихових вршњака, непознатих особа, у институцијама којима је дете поверено на бригу и старање. Манифестације ове појаве су комплексне, а развој нових видова комуникације, посебно интернета, ствара нове облике насиља. То захтева унапређене видове интервенције који омогућавају превенцију и благовремену и адекватну друштвену реакцију у циљу заштите детета.

Систем правне заштите у Србији последњих деценија карактерише постепено унапређење и хармонизација механизама заштите са међународним тенденцијама израженим превасходно у Конвенцији $о$ правима детета (КПД, Сл. лист СФРЈ - Међународни уговори, бр. 15/90 и Сл. лист СРJ - Међународни уговори, бр. 4/96 и 2/97), али и низу других међународних уговора, препорука и инструмената који успостављају најважније међународне стандарде заштите права детета. Претходних година приметан је покушај системског приступа решавању проблема насиља над децом - како на законодавном тако и на институционалном нивоу. Делом, као последица обавеза наше државе, чланице Уједињених нација и Савета Европе, кораци који се непрестано предузимају показатељ су буђења друштва и спознаје присуства озбиљног социјалног проблема чије решавање треба да представља приоритет, а чему је предуслов постојање свеобухватног система заштите. Развојни моменат у коме се такав систем данас налази још увек је недовршен, али су његови основи постављени у Уставу Републике Србије (Сл. гласник $P C$, бр. 98/06), законским и подзаконским прописима, стратешким и другим документима у области заштите детета и породице.

У раду су анализиране карактеристике развоја породичноправне и кривичноправне заштите деце од насиља у Србији, кључни проблеми у спровођењу прописаних мера заштите, као и могућности усавршавања постојећих механизама заштите како на нормативном плану тако и у сфери практичне примене.

\section{ПОРОДИЧНОПРАВНА ЗАШТИТА}

Породични закон (ПЗ, Сл. гласник РС, бр. 18/05, 72/11 и 6/15) представља први унутрашњи пропис којим се прокламују најважнија права детета и посебно уређује грађанскоправна заштита детета од насиља у породици. ${ }^{1}$ Закон у основним одредбама прописује да дете

${ }^{1}$ ПЗ не садржи дефиницију детета, већ у чл. 11 прописује да се пунолетство стиче са навршеном осамнаестом годином, из чега се, посредно, може извести 
ужива посебну заштиту државе и установљава дужност сваког лица да ce, у свим активностима које се тичу детета, руководи најбољим интересима детета (чл. 6). Посебно је предвиђена обавеза државе да предузима све мере које су потребне за заштиту детета од занемаривања, физичког, сексуалног и емоционалног злостављања и сваког облика експлоатације (чл. 6, ст. 2). Закон, међутим, не дефинише наведене форме насиља над децом, нити садржи правна правила којима се посебно регулише заштита детета од различитих облика насиља, већ се таква заштита примарно остварује кроз неколико породичноправних института - заштита од насиља у породици, лишење родитељског права и надзор над вршењем родитељског права. Тиме је заштита детета од насиља стављена у шири контекст грађанскоправне заштите од насиља у породици.

У пракси су приметни различити проблеми који отежавају или онемогућавају примену мера породичноправне заштите детета од насиља. Кључни проблеми тичу се, између осталог, неразумевања и непрепознавања појединих појавних облика насиља над децом, недовољне ангажованости надлежних државних органа - органа старатељства и јавног тужилаштва у погледу благовременог покретања поступака правне заштите, непоштовања начела хитног поступања у судским поступцима за заштиту деце, неспремности судова да у свим случајевима користе своја официјелна и истражна овлашћења, као и, у појединим случајевима, преурањене примене репресивних мера од стране надлежних органа ради искључивог санкционисања родитеља, на који начин се суштински занемарује и остваривање најбољих интереса детета.

ПЗ одређује насиље у породици као свако понашање којим један члан породице угрожава телесни интегритет, душевно здравље или спокојство другог члана породице (чл. 197, ст. 1). Ова широко конципирана законска дефиниција омогућава да се заштита оствари и у случају лакших облика насиља у породици, на који начин се спречава да насиље поприми тежи облик. Законска дефиниција упућује и на неке, у пракси мање препознатљиве, форме насиља. Тако, на пример, изазивање страха претњом убиства или наношења телесне повреде члану породице или њему блиском лицу (чл. 197, ст. 2, т. 2) треба да илуструје ситуације у којима се деца јављају као жртве директног, али и индиректног насиља у породици, када се оно дешава између других чланова породице. Будући да присуство детета ситуацијама партнерског насиља, или насиља између других чланова породице, код детета изазива осећање страха услед претњи које угрожа-

да је дете свако лице које није навршило осамнаест година. Дететом се, према чл. 1 КПД-а, сматра свако лице које није навршило осамнаест година живота, осим ако се по закону који се примењује на дете пунолетство стиче раније. 
вају њему блиско лице, то за последицу има угрожавање душевног здравља и спокојства детета. Истраживање праксе београдских судова показало је да се у највећем броју случајева насиља у породици ради о партнерском насиљу, а да притом у 64,5\% случајева странке у поступку имају заједничку децу (Петрушић, Константиновић Вилић, 2008 , стр. 18). ${ }^{2}$ Тужбу за заштиту од насиља у породици уобичајено подносе мајке као законски заступници детета, при чему су, истовремено, и саме тужиље тражећи заштиту од насиља коме су оне изложене (Ibid, стр. 14). Такође је релативно висок проценат малолетних тужилаца - жртава $(10,8 \%){ }^{3}$ Исто истраживање за територију Србије бележи случајеве насиља између супружника $(35,2 \%)$, бивших супружника, односно бивших ванбрачних партнера (29\%) и између ванбрачних партнера (16\%), при чему се насиље најчешће дешава у заједничком стану (преко 50\%), док у 43,5\% случајева жртва насиља

\footnotetext{
${ }^{2}$ Узнемирујући су подаци из једног од предмета београдских судова: „Тужени је бацио тужиљу на под, тукао је, завртао јој руку и претио пред децом да ће је убити, због чега је једно од малолетне деце изгубило свест..." (Петрушић et al., 2008, стр. 25). Наведени случај из праксе наших судова није, нажалост, усамљен. Образложење једне судске пресуде наводи:

„Мере заштите, њихов број и врста, одмерене су у складу са степеном вербалног насиља које је тужени испољио према тужиљи и предузетим физичким актима, тежини нанетих повреда које је тужиља претрпела и психичком узнемиравању којем је била изложена, посебно имајући при том у виду да се иео догађај одиграо у присуству заједничког малолетног детета странака које је болесно, ито је додатно трауматизовало тужиљу, јер је страховала и за безбедност детета".
}

В. Пресуду Врховног суда Србије, Рев. бр. 849/2006 од 8. 6. 2006. године, Решење Општинског суда у Новом Саду, П бр. 6274/2005 од 30. 9. 2005. године и Пресуду Општинског суда у Новом Саду, П бр. 6274/2005 од 18. 10. 2005. године. Забрињава то што суд није у свом образложењу макар констатовао да наведена понашања представљају и насиље према детету. Уместо тога, присуство болесног детета ситуацији насиља опредељено је само као додатна траума за тужиљу, али не и за дете. Остаје утисак да надлежни органи још увек не сагледавају стварне размере насиља над децом, што се одражава и на потпуно коришћење њихових законских овлашћења и могућности у циљу адекватне заштите детета. Ово потврђују резултати истраживања спроведеног са судијама који суде у породичним споровима према коме 94\% испитаника (од којих највећи број има преко десет година судијског искуства) наводи да никада у свом професионалном раду није имало ниједан случај злостављања деце. Такво уверење је још једна потврда „недовољне препознатљивости феномена насиља у правосудној пракси" (Срна, Тењовић, 2006, стр. 38; Игњатовић, 2013).

3 Ако се наведени проценат упореди са процентом заступљености заједничке деце у преовлађујућем броју случајева партнерског насиља, извесно је да је реалан број деце - жртава породичног насиља, непосредног и посредног - свакако већи. 
(тужиља, одн. тужилац) има двоје деце (Петрушић, Константиновић Вилић, 2010, стр. 43, 53-54).

Када су у питању предвиђене мере заштите од насиља у породици, познато је да су у тексту Нацрта ПЗ, поред важећих заштитних мера, биле садржане и мере: обавезно лечење од алкохолизма и других болести зависности и обавезно саветовање или психијатријско лечење. Штета је што наведене мере нису нашле место у законском тексту имајући у виду да су алкохолизам, злоупотреба психоактивних супстанци, као и различити облици социјалне неприлагођености насилника - фактор који често доприноси појави насиља чије су жртве деца. ${ }^{4}$ За разлику од постојећих мера заштите, ове мере су непосредно усмерене на третман насилника, чему посебан значај придају и најважнији међународни стандарди у овој области.

Из угла заштите деце од насиља, посебну важност има легитимација коју закон даје органу старатељства и јавном тужиоцу, који у овим случајевима делују не само у интересу детета већ и у општем, јавном интересу. С тим у вези, законодавац утврђује право и дужност свих дечјих, здравствених и образовних установа, као и установа социјалне заштите, правосудних и других државних органа, удружења и грађана, да о разлозима за лишење родитељског права обавесте јавног тужиоца или орган старатељства (чл. 263, ст. 3). У пракси, међутим, орган старатељства, а посебно јавни тужилац, ретко иницирају поступак заштите од насиља у породици, што није добро. ${ }^{5}$ За разлику од тога, поступке за лишење родитељског права најчешће покреће орган старатељства, а ређе друга активно легитимисана лица (Жегарац, 2014, стр. 188-189; Републички завод за социјалну заштиту, 2015, стр. 21-22).

У поступцима за заштиту од насиља у породици и за лишење родитељског права важи начело нарочите хитности, које треба да допринесе спречавању понављања насилних понашања и даље виктимизације детета. Похвално је то што су Законом прописани кратки рокови за поступање суда и други заштитни механизми који треба да допринесу ефикасности правне заштите (прво рочиште заказује се у року од осам дана од подношења тужбе, тужба се не доставља туженом на одговор, поступак се спроводи на највише два рочишта, жал-

\footnotetext{
${ }^{4}$ Истраживање судских предмета у вези са поступцима за заштиту од насиља у породици показало је да је у $39,6 \%$ случајева у време вршења насиља тужени био у алкохолисаном стању, док је 2,2\% тужених било под дејством дроге (Петрушић et al., 2010, стр. 62-63).

${ }_{5}^{5}$ Судска пракса показује изузетно мали број случајева у којима је поступак за заштиту од насиља у породици покренуо орган старатељства $-3,4 \%$, односно јавни тужилац - 1\% случајева (Петрушић et al., 2010, стр. 70; Лукић, Јовановић, 2001, стр. 99-104).
} 
ба не задржава извршење пресуде о одређивању мере заштите од насиља у породици и др.). Нажалост, досадашња пракса судова у овој области често је одступала од законом установљених временских захтева ${ }^{6}$, због чега је у последњих неколико година Уставном суду поднето више уставних жалби. ${ }^{7}$

У поступку за лишење родитељског права посебну важност имају одредбе о колизијском старатељству и привременом заступању детета, у ситуацији супротстављених интереса родитеља (као законских заступника) и детета, односно када дете странка није заступано на одговарајући начин. Законом се посебно гарантује и право детета на мишљење и тиме препознаје значај учешћа детета у свим питањима која га се тичу (чл. 65 ПЗ). Посебне дужности у вези са омогућавањем учешћа детета које је способно да формира своје мишљење Закон одређује управо колизијском старатељу, као и привременом заступнику детета. ${ }^{8}$ Када је дете млађег узраста, односно степена развоја који не омогућава непосредно изражавање мишљења детета, улога колизијског старатеља, односно привременог заступни-

\footnotetext{
${ }^{6}$ Истраживања показују да ови поступци у просеку трају од 3 месеца до 6 месеци, а у преко 20\% случајева поступак је трајао дуже од 6 месеци (Петрушић et al., 2010, стр. 99). Породични закон, међутим, не упућује на санкцију која би се могла применити у случају када оперативност суда у решавању случајева породичног насиља неоправдано изостане и прописани рокови не буду испоштовани, што се може сматрати пропустом законодавца.

7 У једном случају, поступак по тужби за измену одлуке о поверавању детета трајао је скоро две године, а тужиља - мајка детета, упркос правноснажности и извршности одлуке којом јој је дете поверено, дуже од шест месеци није успевала да оствари контакт са дететом ,због спорости и неефикасности поступања извршног суда". У току првостепеног поступка, рочиште је више пута одлагано, поступајући судија је мењан, а након закључења главне расправе, расправа је поново отворена, јер судско веће није било састављено у складу са законом. Првостепеном суду било је достављено и мишљење Центра за социјални рад у коме стоји да је у периоду док је малолетно дете било поверено оцу оно, заправо, преко осам месеци било смештено у прихватилишту Центра за заштиту одојчади, деце и омладине, док је Институт за ментално здравље нашао „да се ради о детету које је жртва партнерских сукоба родитеља, чиме је угрожен њен нормалан психофизички развој и да је запажена манипулација детета, чиме је испуњен критеријум озбиљног емоционалног злостављања детета". Уставни суд је усвојио уставну жалбу и утврдио повреду права подноситељке на суђење у разумном року. В. Одлуку Уставног суда, Уж-795/2008 од 3. марта 2011. године (Сл. гласник РС, 029/2011-080).

${ }^{8}$ Поред обавезе да детету омогући благовремено добијање свих обавештења која су му потребна, колизијски старатељ, односно привремени заступник, има посебну дужност да детету пружи објашњење могућих последица акта које он предузима, као и да суду пренесе мишљење детета у случају када дете није непосредно изразило мишљење пред судом, осим када је то очигледно у супротности са најбољим интересом детета. В. чл. 267 ПЗ.
} 
ка, претпоставља и дужност упознавања суда са мишљењем, жељама и потребама детета. Поставља се, међутим, питање способности колизијског старатеља, као и привременог заступника да процењује способност детета да формира своје мишљење, нарочито у случајевима када се у улози колизијског старатеља нађе особа која је лаик (нпр. сродник детета), а у улози привременог заступника адвокат, који нужно не мора поседовати знања потребна за вршење такве процене. Због тога би било корисно размотрити нова нормативна решења која би увела обавезну специјализацију лица која као ванредни, независни законски заступници детета штите његова права и интересе у поступцима из породичних односа (Петрушић, 2006, стр. 189).

У поступку за лишење родитељског права суд је дужан да пре доношења одлуке затражи налаз и мишљење органа старатељства, породичног саветовалишта или друге установе специјализоване за посредовање у породичним односима. У пракси налаз и стручно мишљење судови уобичајено прибављају од органа старатељства. Међутим, упркос томе што мишљење органа старатељства не обавезује суд приликом доношења одлуке и што је суд у обавези да цени све релевантне чињенице и доказе приликом процене најбољег интереса детета, пракса показује да судске одлуке ретко одступају од мишљења органа старатељства, што може бити проблематично у случајевима у којима се у улози странке у поступку јавља управо орган старатељства. ${ }^{9}$ Одлука о потпуном лишењу родитељског права

\footnotetext{
9 Увидом у поједине извештаје центара за социјални рад, стиче се утисак да услед неадекватног баратања чињеницама у неким извештајима посебно долазе до изражаја инсинуације органа старатељства о незаконитим поступањима родитеља, на којима се онда заснивају неосновани закључци и стручна мишљења да родитељи немају потребне родитељске компетенције. На пример, у једном случају у коме је оцу омогућено да виђа троје малолетне деце у контролисаним условима, у просторијама центра за социјални рад (разлог таквог ограничавања родитељског права заснован је на процени органа старатељства да су деца била занемарена), у извештају се наводи да отац ,током контакта доноси слаткише и сокиће деци, отвара им да једу... са њима боји бојанке, даје им мобилни телефон да се играју, шета се ходником... игра ринге ринге раја", и друго, али се потом закључује да отац „друге активности (за децу) није осмислио, нити је покушао да их анимира”, да „није у стању да испрати њихово кретање” и томе слично. Видети Извештај о реализованим контактима, ЦСР К., број 57212 $5857 / 2015$ од 16. 6. 2016. године. Овим се (чини се, намерно) жели навести на погрешан закључак да отац није подобан родитељ, те да га треба потпуно лишити родитељског права (у ком циљу је односни центар већ покренуо поступак пред надлежним судом). Упркос томе што такав закључак ни на који начин не подржавају бројне друге чињенице наведене у истом извештају. Када се наведено има у виду, не може се избећи питање какве то „друге активности”, у овом случају, родитељ треба да осмисли? Да ли орган старатељства жели да укаже да активности које отац већ предузима не одговарају потребама деце? Ако је тако,
} 
мора бити донета уважавањем свих релевантних чињеница и доказа, укључујући и мишљење детета, при чему у том процесу налаз и стручно мишљење органа старатељства представља само једну од смерница за доношење одлуке суда. У супротном, не може се говорити о заштити најбољег интереса детета које је чврсто повезано са правом детета да се, пре свих других, о њему старају родитељи и да му се омогући живот у породичној средини, кад год је то могуће. ${ }^{10}$

Не треба заборавити ни то да дете чији су родитељи потпуно лишени родитељског права има положај детета без родитељског старања, а сваком детету без родитељског старања држава је дужна да обезбеди адекватну заштиту у породичној средини, кад год је то могуће (чл. 20 КПД). Ако се имају у виду правне и друге последице лишења родитељског права (престанак родитељског права, одвајање детета од родитеља, непостојање обавезе за прибављањем сагласности родитеља за заснивање усвојења и др.), постаје јасна неопходност опрезног поступања суда у процесу доношења одлука о лишењу родитељског права. Овакав опрез нарочито захтева могућност секундарне виктимизације детета у случају погрешне процене приликом одређивања мере лишења родитељског права, а у односу на мање рестриктивне мере корективног надзора или заштите од насиља у породици. Начело најмање рестриктивног окружења промовише Закон о социјалној заштити (Сл. гласник $P C$, бр. 24/11, чл. 27),

да ли то онда значи да сви други „подобни” родитељи увек осмишљавају неограничен број различитих активности за своју децу у времену од 90 минута (колико траје посета која је овом оцу омогућена под надзором органа старатељста, и то у „вештачким условима”, у просторијама те исте јавне установе)? Нажалост, у неким случајевима заиста се стиче утисак да се у нашем систему заштите некада користе механизми који се свуда у свету сматрају недопуштеном праксом (у теорији се то назива „намештање” и „гомилање”), а то је пракса која има за циљ да родитеља представи као неподобног, упркос његовим реалним родитељским капацитетима (Жегарац, 2016).

${ }^{10}$ Позитиван пример у том смислу представља судска одлука којом је одбијен тужбени захтев Центра за социјални рад којим је тражено да се мајци детета коja је делимично лишена родитељског права сада та родитељска права одузму у потпуности. Суд је утврдио да у присуству чињенице да „тужена активно тражи посао, редовно виђе дете по моделу утврђеном судском одлуком, објективно није способна да врши сва права из садржине родитељског права (због тренутног стицаја животних околности, прим. ауторки) и објективно није у могућности да сагледа све потребе детета са којим има топао однос и потребу за међусобним виђањем" - нису основани разлози за потпуно лишење родитељског права због, како се у тужби наводи, грубог занемаривања родитељских дужности. Суд је у свом образложењу, уједно, подсетио да „лишавање родитељског права није институт у функцији кажњавања родитеља, већ заштите најбољег интереса детета". В. Пресуду Апелационог суда у Београду, Гж 2 бр. 365/15 од 16. 7. 2014. године и Пресуду Првог основног суда у Београду П2 бр.657/2014 од 27. 4. 2015. године. 
али пракса појединих центара за социјални рад у погледу примене мера корективног надзора указује на то да се ово начело некада не поштује (Жегарац, 2014, стр. 17). Тако су у пракси забележени случајеви у којима се дете путем неодложне интервенције измешта из породице, а потом се покреће поступак за лишење родитељског права како родитеља који је насилан тако и другог родитеља - који је ненасилан, а као разлог се наводи ограниченост родитељских компетенција другог родитеља које су, између осталог, узроковане изложеношћу тог родитеља породичном насиљу (Игњатовић, 2014, стр. 37-58). У извештајима центара за социјални рад ова категорија родитеља подводи се под појам родитеља који „није у могућности да заштити дете од злостављања другог родитеља", што представља најчешћи разлог измештања детета из примарне породице, и то у више од трећине случајева $(38,1 \%)$ у 2011. години, а у значајно већем броју случајева $(48,4 \%)$ у 2012. години (Републички завод за социјалну заштиту, 2013, стр. 74).

Родитељско право може се (и мора) ограничити онда када околности конкретног случаја то оправдавају, када то захтева заштита најбољег интереса детета, односно када се одговарајућа заштита детета није могла остварити применом мање радикалне мере. ${ }^{11}$ Ипак, у нашој судској пракси било је случајева у којима су судови доносили одлуке о потпуном лишењу родитељског права родитеља који спречава остваривање личних односа детета са другим родитељем, не водећи рачуна о квалитету односа детета и родитеља који се лишава родитељског права, а често и без омогућавања детету да о том питању изрази своје мишљење (Делибашић, 2012, стр. 6-7). Овакве судске одлуке своде се на рестриктивно тумачење разлога за потпуно лишење родитељског права којим се тежина изречене мере доводи у несразмеру са циљем због кога се мера лишења родитељског права може одредити, а то је заштита најбољег интереса детета. ${ }^{12}$

\footnotetext{
${ }^{11}$ На то упућују и стандарди Европског суда за људска права, а у том смислу се изјаснио и Врховни суд Србије. В. Пресуду Врховног суда Србије, Рев. бр. $3567 / 2008$.

${ }^{12}$ Исти став потврђује и пракса нашег највишег суда. В. Решење Врховног касационог суда Србије, Рев. бр. 577/2012. Пример опрезног поступања суда везује се, рецимо, за случај у коме је суд правилно проценио да напуштање детета од стране мајке не представља разлог за потпуно лишење родитељског права тужене (мајке детета) с обзиром на то да је мајка дете оставила код својих родитеља у ситуацији када није била у могућности да се о детету адекватно стара, што су родитељи мајке прихватили и обезбедили детету све услове потребне за његов правилан развој. Суд је такође нашао да у конкретном случају нема места ни делимичном лишењу родитељског права имајући у виду да је у току процес успостављања личних односа између мајке и детета, те да лишење родитељског права мајке не би било у складу са најбољим интересом детета. Овим је суд, водећи рачуна о интересима детета, адекватно проценио ситуацију напуштања де-
} 
Одлуком о потпуном лишењу родитељског права суд лишава родитеља свих права и дужности из садржине родитељског права, осим дужности издржавања детета (чл. 81, ст. 4 П3). Родитељ, дакле, увек остаје ималац дужности издржавања детета. У пракси, међутим, бројне одлуке судова не обезбеђују извршење такве дужности родитеља, што не доприноси остваривању најбољег интереса детета.

Са друге стране, законска могућност враћања родитељског права упућује на то да у ситуацијама потпуног лишења родитељског права не престаје одговорност државе у смислу заштите детета. Надлежне државне службе, пре свих Центар за социјални рад, морају настојати да кроз адекватан третман пруже подршку родитељима лишеним родитељског права у обнављању и унапређењу њихових родитељских способности (чл. 5 и 18 КПД). ${ }^{14}$ Таква подршка треба да има за циљ поновно спајање детета са његовим биолошким родитељима, односно омогућавање детету да настави живот у својој примарној породици. У супротном, тешко да се може говорити о обезбеђењу најбољег интереса детета, који је чврсто повезан са правом де-

тета од стране родитеља имајући у виду да је родитељ дете напустио истовремено му обезбеђујући адекватно старање, за разлику од случајева у којима напуштање детета није праћено обезбеђењем услова за старање о детету који, као такав, сигурно представља грубо занемаривање дужности из садржине родитељског права и разлог је због кога родитељу може бити изречена мера потпуног лишења родитељског права. В. Пресуду Окружног суда у Ваљеву, Гж 2 бр. 22/2008 од 28. 2. 2008. године

${ }^{13}$ Током овог истраживања извршен је увид у значајан број судских пресуда у којима ни у једном случају изрека пресуде није садржала одлуку којом се опредељује обавеза издржавања детета од стране родитеља. Чини се да не постоји законска препрека да суд овакву одлуку донесе. Напротив, утисак је да такво овлашћење и обавеза суда проистиче из законских правила о лишењу родитељског права. Имајући у виду неспорну неопходност за хитним поступањем судова у решавању породичноправних питања која се тичу деце, примену начела официјелности, стандард најбољег интереса детета, а посебно одсуство потребе да се води више парничних поступака да би се осигурала потпуна примена законских одредби о лишењу родитељског права, свако друго решење чини се нецелисходним, а свакако доприноси утиску својеврсне незаинтересованости државних органа (овде судова) да се лишење родитељског права изриче са циљем да буде мера привременог карактера.

${ }^{14}$ У својим Закључним запажањима за Републику Србију из 2008. године, Комитет за права детета истиче неопходност примене делотворних мера за обезбеђивање ,jаче подршке и боље социјалне помоћи породицама креирањем једне свеобухватне породичне политике која ће бити оријентисана на дете и која ће омогућити породици да се стара о детету у кући, у свим случајевима где је то могуће, а којом ће се стимулисати добри односи на релацији дете-родитељ” (Committee on the Rights of the Child, 2008, стр. 10). 
тета да се, пре свих других, о њему старају родитељи и да му се омогући живот у породичној средини, увек када је то могуће. ${ }^{15}$

На крају, треба приметити да покретање и вођење поступака грађанскоправне заштите детета од насиља не искључује могућност коришћења механизама казненоправне заштите, уколико у конкретном случају постоје елементи прекршаја или кривичног дела. У том смислу, може се само похвалити опредељење законодавца да се грађанскоправна и казненоправна заштита у овој области допуњују, јер се тако формира основ за свеобухватну правну заштиту детета од насиља.

\section{КРИВИЧНОПРАВНА ЗАШТИТА}

Из угла нормативних оквира кривичноправне заштите деце, могло би се закључити да је она релативно добро уређена и у складу са међународним актима, као и то да законодавац чини помаке у погледу унапређења заштите мењајући поједине инкриминације, предвиђајући нове и пооштравајући казнену политику за дела која се чине на штету малолетних лица.

Законодавац је свој заштитнички став када је у питању разликовање деце и малолетника ${ }^{16}$ код појединих инкриминација мењао, па је 2009. године проширио оквире заштите код дела приказивање порнографског материјала и искоришћавање деце за порнографију, које је постало приказивање, прибављање и поседовање порнографског материјала и искоришћавање малолетног лица за порнографију (чл. 185 КЗ). Ипак, још увек није изменио инкриминацију у чл. 389 КЗ (трговина малолетним лицима ради усвојења), у којој се, противно називу самог дела, као пасивни субјект појављује лице које није навршило 16 година.

Две нове инкриминације израз су поштовања захтева Конвенције Савета Европе о заштити деце од сексуалне експлоатаиије и сексуалног злостављања (Сл. гласник РС - Међународни уговори, бр. $1 / 10)$ - навођење малолетног лица на присуствовање полним радњама (чл. 185a К3) и искоришћавање рачунарске мреже или комуникације другим техничким средствима за извршење кривичних дела

\footnotetext{
${ }^{15}$ Европски суд за људска права је у више наврата утврдио повреду права на поштовање породичног живота из члана 8 Европске конвенције због пропуштања државе да предузме све потребне мере како би се омогућило поновно спајање детета са његовим биолошким родитељима. Видети, нпр., The Case of $K$. A. v. Finland, Application No. 27751/95, 14 January 2003, par. 92.

${ }^{16}$ Док КПД, као и други релевантни међународни документи, дететом сматрају лице које није навршило 18 година, Кривични законик (даље: КЗ) - (Сл. гласник $P C$, бр. 88/05, 107/05, 72/09, 111/09, 121/12, 104/13, 108/14 и 94/16) дететом сматра лице које није навршило 14 година, а малолетником лице које је навршило 14 , али није 18 година (чл. 112 , ст. 8 и 9).
} 
против полне слободе према малолетном лицу (чл. 1856 КЗ). Ипак, наведена дела брзо су постала предмет критике. Критикована је недовољна прецизност и усаглашеност чл. 185a са захтевима Конвенције (Миладиновић-Стефановић, 2014, стр. 569), па је законодавац 2016. године извршио измене, сузивши обим кривичноправне заштите са заштите малолетног лица на заштиту детета, мада то није у супротности са захтевима Конвенције. Нове измене нису отклониле приговоре везане за кривично дело из чл. 1856 (Ibid), иако су неки од њих, недопустиво, техничке природе. Није поштован ни захтев Конвенције везан за инкриминацију коришћења сексуалних услуга малолетних лица (чл. 19в), па би у том смислу требало променити опис дела посредовање у вршењу проституције.

Последње измене КЗ донеле су пооштравање минимума прописане казне за дела из члана 180 , ст. 1 , члана 181 , ст. 3 . и 4 , али и три нова дела, као одговор на међународноправне захтеве ${ }^{17}$ : полно узнемиравање (чл. 182a), које добија тежи облик ако је учињено према малолетном лицу, принудно закључење брака (чл. 187a) и прогањање (чл. 138a), док је у члану 191 (одузимање малолетног лица) предвиђен тежи облик када је дело учињено према новорођенчету. Имајући у виду још увек присутан проблем принуде на склапање брака малолетника, обично малолетница из ромске заједнице (Алексић, 2015), требало је предвидети тежи облик дела у члану $187 \mathrm{a}$.

Уочена је потреба за прецизирањем још неких инкриминација, односно за променом ставова судске праксе, што би омогућило бољу заштиту малолетних лица. Тако би, на пример, под радњу силовања и других кажњивих обљуба требало подвести и пенетрације другим деловима тела или предметима. Такође, законодавац није приликом измена КЗ одговорио на замерку Комитета за права детета која се односи на инкриминацију продаје детета у складу са одредбама чл. 2 и $3 \mathrm{On}$ ичиног протокола уз КПД о продаји децее, дечјој порнографији и дечјој проституцији (Committee on the Rights of the Child, 2010, стр. 2).

Заоштравање законодавне казнене политике донело је и забрану ублажавања казне за нека дела која се чине на штету малолетних лица, као и у случају раније осуђиваности за истоврсно кривично дело, а ограничено је и условно отпуштање осуђених за поједина дела (чл. 46, ст. 2 и чл. 57, ст. 2 и 3 КЗ). Ова решења се критикују, нарочито забрана ублажавања казне (Делић, 2010), и доводе се у везу са пунитивно-популистичким захтевима, који су свој екстремни израз добили у Закону о посебним мерама за спречавање вршења кривичних дела против полне слободе према малолетним лицима (Сл.

\footnotetext{
17 Тачније, захтеве Конвенције Савета Европе о спречавању и борби против насиља над женама и насиља у породици (Сл. гласник $P C-$ Међународни уговори, бр. 12/13).
} 
гласник $P C$, бр. 32/13). Овај закон донет је после трагичног догађаја силовања и убиства осмогодишње девојчице, без много правничког промишљања, утврђивања везе са сродним законским (и уставним) решењима, па ни са релевантним међународноправним, ${ }^{18}$ и евалуације резултата које су дали слични покушаји у свету ${ }^{19}$. Наиме, истраживања показују да малолетна лица преовлађују у броју жртава регистрованих сексуалних деликата, да су учиниоци најчешће особе које деца познају и којима верују, уз изражену родну компоненту (Ђорђевић, Симеуновић-Патић, 2015, стр. 229; Богавац, Оташевић, 2015, стр. 7-8). С тим у вези не чуде напори да се побољша заштита деце у овој сфери, али инсистирање на репресији према учиниоцима неће омогућити ефикасну заштиту. У поменутом закону акценат је на одвраћању/спречавању учиниоца да понови дело, будући да се мере примењују тек када је учинилац правноснажно осуђен, односно када је издржао казну ${ }^{20}$, мере више личе на „нове казне”, начин њиховог извршења није разрађен, а са сигурношћу се може предвидети стигматизација осуђеног и његово изопштење из друштва, што не може допринети бољој заштити деце у смислу превенције ${ }^{21}$. Могло би се закључити да се овај закон показао више као формални израз бриге државе за добробит деце и потребе за специфичном интервенцијом у случајевима сексуалног насиља и као добар пример лоше за-

\footnotetext{
${ }^{18}$ Recommendation CM/Rec (2014)3 of the Committee of Ministers to member States concerning dangerous offenders, https://search.coe.int/cm/Pages/result_details.aspx? ObjectID $=09000016805 \mathrm{c} 649 \mathrm{~d}(15.1 .2018)$.

${ }^{19}$ Упозорава се да „меморијална криминална политика”, стварана у жару реаговања на трагичне и тешке, али ретке случајеве сексуалног насиља праћеног убиством детета, примењена на све сексуалне преступнике, производи више нових проблема него користи. D. J. Williams, J. N. Thomas, E. E. Prior (2015) „Moving Full-Speed Ahead in the Wrong Direction? A Critical Examination of US Sew-Offender Policy from a Positive Sexuality Model", Critical Criminology, стр. 118 (Ђорђевић et al., 2015, стр. 233).

${ }^{20}$ Мере предвиђене чланом 7 овог закона су: обавезно јављање надлежном органу полиције и Управе за извршење кривичних санкција; забрана посећивања места на којима се окупљају малолетна лица (вртићи, школе и сл.); обавезно посећивање професионалних саветовалишта и установа; обавезно обавештавање о промени пребивалишта, боравишта или радног места; обавезно обавештавање о путовању у иностранство.

${ }^{21}$ Критикује се и забрана примене три општа института кривичног права (забране ублажавања казне, забране условног отпуштања и застарелости кривичног гоњења и извршења казне). Тако, понављање дела за која је већ забрањено ублажавање казне за дела предвиђена у КЗ оцењује се као излишно (Ристивојевић, 2013, стр. 331), а проширивање забране ублажавања и на друга дела додатно компликује питање оправданости ове забране и отвара питања логике по којој је законодавац поступао. Забрана условног отпуштања осуђених за ова дела је такође проблематична и није у складу са одредбама КЗ, а слично је и са незастаревањем ових дела (Ђорђевић et al., 2015, стр. 239-240).
} 
конодавне праксе и „паничног законодавства”, уместо да буде добро промишљени потез који би унапредио заштиту деце. Укратко, поједине одредбе овог закона се преклапају, а поједине су у колизији са одредбама КЗ, а закон је споран и са аспекта поштовања људских права учинилаца (Ђорђевић et al., 2015, стр. 237-241; Мрвић-Петровић: 2015, стр. 212-215; Павловић, 2014, стр. 11; Ристивојевић, 2013) ${ }^{22}$. Такође, на листи кривичних дела коју даје овај закон недостају она која и те како погађају малолетна лица (родоскрвњење и трговина људима), што је још један аргумент у прилог констатацији да је законодавац поступио прилично непромишљено, у журби, без јасног система и са изразито ретрибутивном мотивацијом. Велика очекивања јавности прате и Закон о спречавағу насиља у породици (Сл. гласник РС, бр. 94/16), али ни критика не изостаје (Лазић, Ненадић, 2017). Један од разлога за његово доношење јесте утврђено непостојање адекватне координисане сарадње између релевантних државних органа, па се поставља питање чему су служили постојећи бројни протоколи о поступању и сарадњи.

Конвенција о спречавању и борби против насиља над женама и насиља у породици захтева строже казне за физичко, сексуално и психолошко насиље учињено према детету или у присуству детета. Према Конвенцији, уколико ова околност није обележје дела, мора се ценити као отежавајућа (чл. 46, ст. 1д). Међутим, судска пракса показује да се околност да је дело учињено у присуству детета најчешће не цени као отежавајућа, што потврђују новија истраживања правосудне праксе за кривично дело насиље у породици, као и истраживања фемицида у Србији (Јовановић, Симеуновић-Патић, Мацановић, 2012, стр. 38-40, 126-127; Сименуовић-Патић, Јовановић, 2013, стр. 164-165). Апсурдно је да се околност да је учинилац родитељ цени као олакшавајућа и у случајевима насиља у породици ${ }^{23}$ или убиства жене - мајке деце, према којој је учинилац такође био насилан $(\mathrm{Ibid}){ }^{24}$

\footnotetext{
22 Критикује се и забрана примене три општа института кривичног права (забране ублажавања казне, забране условног отпуштања и застарелости кривичног гоњења и извршења казне). Тако, понављање дела за која је већ забрањено ублажавање казне за дела предвиђена у КЗ оцењује се као излишно (Ристивојевић, 2013, стр. 331), а проширивање забране ублажавања и на друга дела додатно компликује питање оправданости ове забране и отвара питања логике по којој је законодавац поступао. Забрана условног отпуштања осуђених за ова дела је такође проблематична и није у складу са одредбама КЗ, а слично је и са незастаревањем ових дела (Ђорђевић et al., 2015, стр. 239-240).

${ }^{23}$ Тако је суд ценио као олакшавајућу околност (код члана 194, ст. 2 К3) то што је „окривљени отац петоро деце”, губећи из вида да је окривљени кривично дело извршио према једном од петоро деце, које је претукао и везао. У другом случају, суд погрешно цени као олакшавајућу околност „да је окривљени отац
} 
Проблем је и непризнавање статуса оштећених деци у чијем је присуству вршено насиље, иако има основа за овакво тумачење имајући у виду законски опис дела насиље у породици (Јовановић et al., 2012, стр. 126). Забрињавајуће је и то што жене-мајке које трпе насиље добијају савете у центрима за социјални рад да се „помире са мужем” или „да му се врате, а све ради 'добробити деце”" (Игњатовић, 2013, стр. 16), што је погрешно и опасно тумачење најбољег интереса детета. Утврђена је и пракса покретања поступака надзора над вршењем родитељских права, делимичног или потпуног лишења родитељских права према мајкама иако су оне идентификоване као жртве насиља у породици, као и пракса издвајања деце из породице у ситуацијама када је процењено да „родитељ није у могућности да заштити дете од злостављања другог родитеља" (Ibid, стр. 21).

Конвенција Савета Европе о борби против трговине људима (Сл. гласник РС-Међународни уговори, бр. 19/09) предвиђа посебне мере и процедуре када су жртве деца зарад правовремене идентификације и ефикасне заштите и избегавања ризика ревиктимизације и секундарне виктимизације. Извештаји Центра за заштиту жртава трговине људима показују да деца чине преко половине идентификованих жртава (Центар за заштиту жртава трговине људима, 2015), а капацитети система социјалне заштите ограничени су када је реч о пружању помоћи и заштите, па највећи терет у тој сфери носе и даље невладине организације (Атина, Астра). Како систем „функционише”, показало се најбоље у време „мигрантске кризе”. Деца као жртве трговине људима или друге врсте насиља нису препознавана чак ни у случајевима присуства очигледних показатеља виктимизације, а у појединим случајевима изостајао је кривични прогон учинилаца иако је дошло до идентификације жртава (НВО Атина, 2016, стр. 4). Ни деца без пратње нису остваривала своја права, а у случајевима екстремног насиља, пријављеног државним органима, систем заштите се активирао, али неадекватно. Тако се дешавало да децу прати више привремених старатеља, да су деца смештана у прихватне центре без икаквих прилагођених програма, преводилаца и др. (Јовановић, 2016). Истраживање које је подразумевало разговор са жртвама трговине људима (међу којима је било и малолетних) показало је

малолетног детета", иако је насиље управо вршио према том детету старом свега четири и по године.

${ }^{24} \mathrm{C}$ тим у вези, Врховни суд Србије утврдио је „да учиниоцу кривичног дела убиства када је извршењем дела усмртио супругу са којом има четворо малолетне деце, то што је отац четворо малолетне деце не може представљати олакшавајућу околност, иако обавеза издржавања четворо малолетне деце представља олакшавајућу околност”. В. Пресуду ВСС Кж. 744/05 од 30. јуна 2005. и Пресуду Окружног суда у Смедереву К. 79/04 од 30. децембра 2004. године. 
високи степен незадовољства услугама система социјалне заштите, а у одговорима је апострофиран неадекватан однос (непрофесионалан, некоректан) запослених према жртвама (Морача et. al., 2013, стр. 125129). На потребу за појачавањем напора у области спречавања трговине децом и заштите деце без пратње упућује и најновији извештај о $п р и$ мени Конвенције о борби против трговине ьудима (GRETA, 2017, стр. 27).

Вршњачко насиље је и даље актуелна тема, а у последње време је у средишту пажње родно засновано насиље, које представља распрострањену форму вршњачког насиља (UNICEF, 2015, стр. 8). Кривичноправни одговор на проблем вршњачког насиља показао се као не толико значајан и истраживан, за разлику од програма превенције, на којима треба инсистирати и даље ${ }^{25}$. Недавно спроведено истраживање насиља у породици чији су извршиоци малолетници указује на постојање чврсте везе између насиља у породици чије су малолетници жртве и насиља које су они вршили према својим вршњацима, а некада и родитељима (Јовановић, Софреновић, 2016). Утврђено је и да школе нису на одговарајући начин реаговале када су у питању ови малолетни делинквенти, иако су имале информације о томе да се ради о деци која не долазе на наставу и „проблематичног” су понашања у школи и ван ње. Слично је и са центрима за социјални рад. Констатован је и недостатак смислених програма за родитеље (и уопште породице) деце којој је помоћ потребна било пре него што је дошло до активирања кривичноправног механизма (Ibid) или након тога. Да школа не реагује адекватно на случајеве насиља у школи показују и резултати истраживања према којима је $24,7 \%$ испитаних основаца изјавило да нико од наставника или само неколико наставника доследно реагује када са појави насиље у школи, а чак половина њих $(46,3 \%)$ каже да, када се неко насилно понаша према њему/њој, поступци наставника веома ретко или само понекад помажу да се те ситуације реше (Попадић et al., 2014, стр. 238).

У погледу заштите деце од секундарне виктимизације у кривичном поступку, треба похвалити рад мобилних јединица који је удахнуо живот нормама Закона о малолетним учиниоцима кривичних дела и кривичноправној заштити малолетних лицуа (Сл. гласник РС, бр. $85 / 05)$. Наиме, одредбе које треба да обезбеде заштиту деци жртвама насиља нису у пракси примењиване на одговарајући начин, што је резултирало ускраћивањем адекватне заштите деци жртвама и сведоцима. Резултати истраживања показују да се принцип најбољег интереса детета не поштује и не тумачи на прави начин у кривичном поступку, те да се не води рачуна о хитном поступању, да је неуједначена судска

${ }^{25}$ В. резултате истраживања и препоруке дате у: Попадић, Плут, Павловић, 2014. 
пракса по питању постављања пуномоћника малолетном оштећеном, заштите приватности и идентитета детета током кривичног поступка, заштите безбедности детета и његове породице, недовољне заступљености и активности органа старатељства у кривичном поступку и др. (Банић, Стевановић, 2015, стр. 40-41). Нажалост, и са̂м Законик о кривичном поступку (Сл. гласник $P C$, бр. 72/11, 101/11, 121/12, 32/13 и 55/14), иако предвиђа правила за заштиту посебно осетљивог сведока, не искључује могућност његовог унакрсног испитивања, што води секундарној виктимизацији детета, те би такву могућност требало искључити.

Оваква ситуација довела је до реализације пројекта „Унапређивање права детета кроз јачање система правосуђа и система социјалне заштите", у оквиру кога су формиране четири мобилне јединице за подручје апелационих судова, које пружају помоћ малолетним оштећенима/сведоцима приликом давања исказа, истовремено обезбеђујући и квалитетнији исказ органима поступка. ${ }^{26}$ Имајући у виду добре резултате овог пројекта, требало би указати на значај потребе за његовом институционализацијом.

\section{УМЕСТО ЗАКЉУЧКА}

Постојећи нормативни оквир заштите деце од насиља је релативно добро уређен и усклађен са међународноправним захтевима и препорукама. Ипак, пречесто у журби и са жељом да се тек формално испуне преузете обавезе, а уједно задовоље и захтеви јавности за репресијом, он је мењан, допуњаван, уз чињење битних пропуста и без вођења рачуна о међусобној усклађености прописа. Пример таквог, исхитреног, реаговања јесте Закон о посебним мерама за спречавање вршења кривичних дела против полне слободе према малолетним лицима, који трпи озбиљне критике, са спорним превентивним учинцима. Са друге стране, Закон о спречавању насиља у породици је донет, између осталог, због тога што је утврђено да не постоји коор-

\footnotetext{
${ }^{26}$ Поступак се спроводи тако што је дете са стручњаком у једном просторији, а стручњак путем бубице слуша питања, прилагоди их како би дете најбоље разумело. Дешава се да испитивање траје и више од три сата, али се дете након тога не позива и тако додатно не виктимизује. Јединице располажу потребном мобилном опремом (камере, компјутери) која омогућава пренос слике и звука како би се узео исказ (обично у тужилаштву или у Прихватилишту за ургентну заштиту злостављане деце). У Београду је за годину и по дана рада 19-оро деце било обухваћено овим поступком, а око 30-оро на нивоу Србије. Подаци о мобилним јединицама обезбеђени су вођењем интервјуа са Иваном Милосављевић-Ђукић, координаторком Прихватилишта за ургентну заштиту злостављане деце, дана 3. 11. 2016. године.
} 
динисано деловање релевантних државних органа, упркос постојању посебних законских прописа, као и протокола о поступању и сарадњи.

Поред поправљања нормативног оквира, неопходне су измене правосудне праксе, која такође трпи примедбе, а разлози за то су најчешће већ усвојено, уходано поступање, несензибилисаност и ригидност актера. Тако се деца некада прерано измештају из примарне породице, некада се смештају у неадекватне услове у институцијама где предуго остају, често су изложена премештајима из једног смештаја у други, при чему наведене и друге мере које се предузимају у циљу заштите деце уопште не одговарају на њихове потребе. Такве реакције система заштите у крајњем исходу само отежавају већ довољно тешку ситуацију у којој се налази дете жртва насиља. Уз то, још увек је присутан проблем недовољне међусекторске сарадње, одсуства механизама за праћење регистрованих случајева насиља, недовољна је обученост професионалаца у систему, као и њихова спремност да деци, њиховим родитељима и другим члановима породице омогуће адекватно учешће у поступку који се иницира у циљу заштите детета, уз уважавање реалних капацитета породичног окружења да деци обезбеди адекватну заштиту. У том смислу, заиста се чини пресудном примена механизама превенције, подстицањем снага породичне мреже, како би се умањио број случајева у којима се деца измештају из породичног окружења. Са друге стране, спречавање деликата са елементима насиља не треба заснивати првенствено на репресији или превенцији коју обезбеђују кривичноправне мере (jер би кривично право требало да буде последње средство заштите), већ, имајући у виду да су преступници веома често они који су најближи детету, унапред спречити виктимизацију делотворним мерама социјалне заштите и породичног права, уз обавезно координисано деловање свих актера како у препознавању ризика тако и у његовом неутралисању и обезбеђењу адекватне заштите детета од насиља, уз пуно уважавање најбољег интереса детета.

\section{ЛИТЕРАТУРА}

Алексић, М. (2015). Дечји бракови у Србији: анализа стања и препоруке [Child marriages in Serbia: state of affairs and recommendations]. Београд: Фондација Ана и Владе Дивац.

Банић, М., Стевановић, И. (2015). Како до правосуђа по мери детета Заштита деце жртава у кривичним поступщима и стање у пракси Републике Србије [Judical system - Protection of child victims in criminal proceedings, and state of affairs in Serbian judicial practice]. Београд: Центар за права детета. 
Богавац, Љ., Оташевић, С. (2015). Прва национална студија о друштвеном проблему сексуалног злостављања деце у Републици Србији: кратак прелиминарни извештај. ,Yes, I ат”, Први стручни часопис у Србији за превениију сексуалног насиља, 5, http://www.incesttraumacentar.org.rs/files/ 2015/Preliminarni\%20izvestaj\%20-\%20ITC\%20Nacionalna\%20studija\%202015. pdf (17. 1. 2018).

Committee on the Rights of the Child (2008). Concluding observations: Republic of Serbia. CRC/C/SRB/CO/1. 20 June 2008.

Committee on the Rights of the Child (2010). Consideration of reports submitted by state parties under article 12(1) of the Optional protocol to Convention of the rights of the child on the sale of children, child prostitution and child phornography, Concluding observations of the Committee on the Rights of the Child: Republic of Serbia. CRC/C/OPSC/SRB/CO/1. 22 June 2010.

Council of Europe, GRETA (2018). Report concerning the implementation of the CoE Convention on Action against Trafficking in Human Beings by Serbia.

Делибашић, 3. (2012). Права детета у спору за заштиту права детета и у спору за вршење односно лишење родитељског права [Child rights in a dispute for protection of rights of the child and in a dispute for exercise or deprivation of parental rights]. http://www.bg.ap.sud.rs/images/ZORANA\%20DELIBASIC_ PRAVA\%20DETETA.pdf (15. 1. 2018).

Делић, Н. (2010). Забрана (искључење) ублажавања казне у одређеним случајевима [Ban (exclusion) of penalty mitigation in certain cases]. Crimen, $2,228-245$.

Ђорђевић, Ђ., Симеуновић-Патић, Б. (2015). Малолетна лица као жртве кривичних дела против полне слободе [Minors as victims of crimes againts sexual freedom]. У: Стевановић, И. (ур.) Малолетници као учиниоции и жртве кривичних дела и прекриаја, Београд: Институт за криминолошка и социолошка истраживања, 227-244.

Жегарац, Н. (2016). Од проблема до прилика у вођењу случаја: приручник за практичаре [From problems to possibilities in case managing: manual for practitioners], Београд: Универзитет у Београду Факултет политичких наука, Центар за истраживања у социјалној политици и социјалном раду.

Жегарац, Н. (2014). У лавиринту социјалне заштите: поуке истраживања о деци на породичном и резиденцијалном смештају [In social welfare labyrinth: lessons from research on children in family and residential accomodation]. Београд: Универзитет у Београду Факултет политичких наука, Центар за истраживања у социјалној политици и социјалном раду.

Игњатовић, Ђ. (2009). Претпоставке за изградњу модела контроле криминалитета у новом миленијуму - крос-национална пепрспектива [Presumtions for creation of crime control model in new millenium - cross-national perspective]. У: Крон, Л. (ур.) Контрола криминалитета и европски стандарди: стање у Србији, Београд: Институт за криминолошка и социолошка истраживања, 19-51.

Игњатовић, Т. (2013). Последище које има насиље према женама у партнерским односима на деиу и одговор јавних служби на овај проблем [Cоnsequences of intimate partner violence against women on children, and the response of public services to the problem]. Београд: Аутономни женски центар.

Игњатовић, Т. (2014). Родитељ није у могућности да заштити дете од злостављања другог родитеља - о чему се ради и шта је рађено [Parent cannot protect the child from the other parent's abusive behavior - what is the matter and what has been done]. У: Мршевић, 3., Јовановић, С., Лукић, М., Игњатовић, Т. Годишьи извештај опсерваторије за праћење насиьа према женама 2013. 
Београд: Мрежа Жене против насиља и Мрежа за европски женски лоби, Београд, 36-60.

Јовановић, С. (2016). Проблеми остваривања заштите малолетних миграната у ризику од трговине људима: наша или туђа „мигрантска криза”? [Challenges in enforcement of protection of minor migrants at risk of human trafficking: ours or someone else's ,migrant crises“?]. У: Ћирић, Ј., Кнежић, Б. (прир.) Мигранти на раскршћу или беспућу земље Србије, Београд: Институт за упоредно право, Институт за криминолошка и социолошка истраживања, 167-184.

Јовановић, С., Симеуновић-Патић, Б. (2012). Кривичноправни одговор на насиље y породици у Војводини [Criminal justice response to family violence in Vojvodina]. Нови Сад: Покрајински секретаријат за рад, запошљавање и равноправност полова.

Јовановић, С., Софреновић, В. (2016). Малолетни учиниоци насиља у породици: жртве дисфункционалне породице и недовољне бриге друштва [Juvenile perpetrators of family violence: victims of disfunctional family and unsufficient care of society]. У: Гајин, С. (ур.) Положај детета у кривично-правном систему. Београд: Центар за унапређивање правних студија, 57-82.

Лазић, Р., Ненадић, С. (2017). Јавно тужилаштво пред изазовима Закона о спречавању насиља у породици [Public Prosecution Office facing challenges of the Act on domestic violence prevention]. У: Бејатовић, С. (ур.) Реформски процеси и поглавље 23 (годину дана после) - кривичноправни аспекти. Београд: Српско удружење за кривичноправну теорију и праксу, 491-502.

Миладиновић-Стефановић, Д. (2014). Кривичноправна заштита малолетних лица од сексуалног искоришћавања и злостављања - европски стандарди и право Републике Србије [Criminal justice protection of juveniles from sexual exploitation and abuse - European standards and law of the Republic of Serbia]. Зборник радова Правног факултета у Нииу, 68, 567-584.

Морача, Т., Галоња, А., Јовановић, С., Миленковић, Л. (2013). Локалне заједниче у борби против трговине људима [Local communities in the fight against human trafficking]. Београд: Удружење грађана за борбу против трговине људима и свих облика насиља над женама - Атина.

Мрвић-Петровић, Н. (2015) Legal problems in using preventive detention or preventive supervision of offenders dangerous to society. У: Коларић, Д. (yp.) Archibald Reiss Days, Belgrade: Academy od Criminalistic and Police Studies, Belgrade, 2, 211-218.

Павловић, 3. (2014). Кривичноправно реаговање на насиље над децом [Criminal justice response to violence againts children]. У: Коларић, Д. (ур.) Насиље y Србији: узроии, последище и друштвене реакиије, Београд: Криминалистичкополицијска академија, Фондација „Hans Zajdel”, 2, 1-13.

Петрушић, Н. (2006). Заступање детета у парници [Representing the child in litigation]. Правни живот, 10(2006), 169-192.

Петрушић, Н., Константиновић Вилић, С. (2008). Породичноправна заштита од насиьа у породиии у пракси судова у Београду [Family law protection from family violence in the judicial practice in Belgrade]. Београд: Аутономни женски центар и Женски истраживачки центар за едукацију и комуникацију.

Петрушић, Н., Константиновић Вилић, С. (2010). Породичноправна заштита од насиља у породици у правосудној пракси Србије [Family law protection from family violence in the judicial practice in Serbia]. Београд: Аутономни женски центар и Женски истраживачки центар за едукацију и комуникацију. 
Попадић, Д., Плут, Д., Павловић, 3. (2014). Насиље у школама у Србије: Анализа стања од 2006. до 2013. водине [Violence in schools in Serbia: State of affairs analysis from 2006 to 2013]. Београд: Институт за психологију, UNICEF, Београд.

Републички завод за социјалну заштиту (2013). Синтетизовани извештај о раду иентара за соиијални рад у Србији за 2012. gодину [Synthesized report on the work of social welfare centers in Serbia in 2012]. Београд.

Републички завод за социјалну заштиту (2015). Деца у систему соиијалне заштите 2015 [Children in the social welfare system 2015]. Београд.

Ристивојевић, Б. (2013). „Пунитивни популизам” српског законодавца - критичка анализа тзв. Маријиног закона [„Рunitive populism“ of the Serbian legislator critical analysis of the so called „Maria's law"]. У: Бејатовић, С. (ур.) Нова решења у казненом законодавству Србије и ғихова практична примена, Београд: Српско удружење за кривичноправну теорију и праксу, 319-338.

Симеуновић-Патић, Б., Јовановић, С. (2013). Жене жртве убиства у партнерском односу [Women victims of homicide in partner relationship]. Београд: Институт за криминолошка и социолошка истраживања.

Срна, Ј., Тењовић, Л. (2006). Митови о насиљу код стручњака у правосуђу [Myths about violence among judiciary professionals], Темида, 9 (4), 35-42.

Стевковић, Љ. (2012). Посредна виктимизација деце као фактор ризика насилног криминалног понашања у одраслом добу [Indirect victimization of children as a risk factor for criminal behavior in adulthood]. Зборник Института за криминолошка и социолошка истраживања, 2, 239-250.

Стојановић, 3. (2006). Коментар Кривичног законика [Commentary on the Criminal Code]. Београд: ЛП „Службени гласник”.

Ћериман, J., Духачек, Н., Перишић, К., Богдановић, М., Духачек, Д. (2015). Истраживање родно заснованог насиља у школама у Србији [Gender based violence research in schools in Serbia]. Београд: Центар за студије рода и политике, Факултет политичких наука Универзитета у Београду, UNICEF.

Центар за заштиту жртава трговине људима (2015). Основни статистички извештај о идентификаџији жртава трговине људима за 2015. годину, http://www.centarzztlj.rs/images/stat/15/Statisticki\%20izvestaj\%20za\%20201 5.\%20godinu.pdf (17. 1. 2018)

\section{Међународни инструменти и национални прописи}

Закон о посебним мерама за спречавање вршења кривичних дела против полне слободе према малолетним лицима, Сл. гласник РС. Бр. 32 (2013)

Закон о социјалној заштити, Сл. гласник РС. Бр. 24 (2011)

Закон о спречавању насиља у породици, Сл. гласник РС. Бр. 94 (2016)

Закона о малолетним учиниоцима кривичних дела и кривичноправној заштити малолетних лица, Сл. гласник РС. Бр. 85 (2005)

Законик о кривичном поступку, Сл. гласник РС. Бр. 72 (2011), 101 (2011), 121 (2012), 32 (2013) и 55 (2014)

Конвенција о правима детета, Сл. лист СФРЈ-Међународни уговори. Бр. 15 (1990) и Сл. лист СРЈ-Међународни уговори. Бр. 4 (1996) и 2 (1997)

Конвенција Савета Европе о борби против трговине људима, Сл. гласник РС Међународни уговори. Бр. 19 (2009)

Конвенција Савета Европе о заштити деце од сексуалне експлоатације и сексуалног злостављања, Сл. гласник РС - Међународни уговори, Бр. 1 (2010)

Конвенција Савета Европе о спречавању и борби против насиља над женама и насиља у породици, Сл. гласник РС - Међународни уговори. Бр. 12 (2013). 
Кривични законик, Сл. гласник РС, Бр. 88 (2005), 107 (2005), 72 (2009), 111 (2009), 121 (2012), 104 (2013), 108 (2014) и 94 (2016)

Породични закон, Службени гласник РС. Бр. 18(2005), 72(2011) - др. закон, 6(2015). Recommendation CM/Rec (2014)3 of the Committee of Ministers to member States concerning dangerous offenders, https://search.coe.int/cm/Pages/result_details. aspx?ObjectID=09000016805c649d (15.1.2018)

Устав Републике Србије, Сл. гласник РС. Бр. 98 (2006).

\title{
PROTECTION OF CHILDREN FROM VIOLENCE IN SERBIA: CURRENT LEGAL ISSUES AND PROBLEMS
}

\author{
Slađana Jovanović, Jelena Arsić \\ Union University, School of Law, Belgrade, Serbia
}

\begin{abstract}
Summary
Over the last several decades, the system of legal protection of children from violence in Serbia has been gradually improving and its protection mechanisms have been harmonizing with international law tendencies primarily set out in the Convention on the Rights of the Child, as well as in a number of other international treaties, recommendations, and other documents establishing the most important international standards for the protection of the rights of the child. Partially, as the consequence of obligations of our state as the member of the United Nations and the Council of Europe, the steps that are continuously undertaken are an indicator of the society's awakening and awareness of the presence of a serious social problem of violence against children, whose resolution should be a priority grounded on a comprehensive and complete system of child protection as a prerequisite. The developmental moment in which such a system is located today is still unaccomplished, but its foundations are set out in the Constitution of the Republic of Serbia, as well as in other regulations, strategic and other documents in the area of child and family protection.

The Family Act of the Republic of Serbia stipulates the obligation of the state to take all measures necessary to protect the child from neglect, physical, sexual and emotional abuse, and from any form of exploitation. This act, however, does not define the forms of violence against children, nor does it contain legal provisions specifically regulating the protection of the child from various forms of violence, but such protection is directly achieved through several family law institutes - protection from domestic violence, deprivation of parental rights, and supervision over the exercise of parental rights. Key problems related to the implementation of measures of the family law protection of children from violence include, inter alia, non-compliance with the principle of urgency in court proceedings for the protection of children, misunderstanding and non-recognition of certain forms of violence against children, insufficient engagement of competent state authorities - the guardianship authority and the Public Prosecutors' Office in terms of the timely initiation of legal protection proceedings, the unwillingness of courts to use their official and investigative powers in all cases, and, in some cases, prematurely applied repressive measures by the competent authorities for the exclusive sanctioning of the parents, thereby essentially neglecting the best interests of the child. The normative framework for the criminal law protection of children from violence is relatively well regulated and harmonized with international legal requirements and recommendations. However, it has been changing frequently, too often in a hurry and with the desire to
\end{abstract}


formally fulfill the undertaken obligations, but also to meet the public demands related to repression, while very significant failures have been made, and even mutual compliance of the legal regulations has been neglected. Beside the normative framework improvements, changes in the judicial practice are of the great importance, as well as changes in the procedures of other relevant subjects involved in the system of protection of children from violence (so far characterized by insufficient sensitivity and rigidity of the actors), emphasizing coordinated cooperation in the best interest of the child. 